\title{
AMERICAN LIVING STANDARDS: EVIDENCE FROM RECREATIONAL EXPENDITURES
}

\author{
Dora L. Costa
}

Working Paper 7148

http://www.nber.org/papers/w7148

\author{
NATIONAL BUREAU OF ECONOMIC RESEARCH \\ 1050 Massachusetts Avenue \\ Cambridge, MA 02138 \\ May 1999
}

I have benefited from comments of Jerry Hausman, Matthew Kahn, and of workshop participants at Columbia, Davis, Toronto, Queens, and McGill. I gratefully acknowledge the support of NIH grant AG12658. All opinions expressed are those of the authors and not those of the National Bureau of Economic Research.

(C) 1999 by Dora L. Costa. All rights reserved. Short sections of text, not to exceed two paragraphs, may be quoted without explicit permission provided that full credit, including (C) notice, is given to the source. 
American Living Standards:

Evidence from Recreational Expenditures

Dora L. Costa

NBER Working Paper No. 7148

May 1999

JEL No. D12, D63, N11, N12

\section{ABSTRACT}

I use consumer expenditure surveys from 1888-1890, 1917-1919, 1935-1936, 1972-1973, and 1991 to determine whether trends in real income per capita are consistent with trends in recreational budget shares and to establish trends in inequality in recreational expenditures. I find that changes in real total expenditures per capita are likely to underestimate the increase in living standards, particularly during times of innovation in consumer goods and reductions in hours such as in the $1920 \mathrm{~s}$ and the $1970 \mathrm{~s}$ and $1980 \mathrm{~s}$. Real per capita total expenditures fell by 1.2 percent per year between 1919 and 1935 and rose by 1.8 percent per year between 1972 and 1991. In contrast, trends in recreational expenditure shares imply that between 1919 and 1935 real per capita total expenditures rose by 1.2 percent per year and between 1972 and 1991 by 3.6 percent per year. The bias in conventional measures of per capita real total expenditures may therefore have been 2.4 percentage points per year between 1919 and 1935 and 1.8 percentage points per year between 1972 and 1991. I also find that lower income households experienced a larger increase in living standards than higher income households, perhaps because of decreases in the work hours of lower relative to higher income workers, technological change that lowered the price of recreational goods and created new products that increased demand for recreation, and increased public provision of recreational goods.

Dora L. Costa

MIT

Department of Economics, E52

50 Memorial Drive

Cambridge, MA 02139

and NBER

costa@mit.edu 
Real income is an imperfect measure of trends in living standards. Current income numbers are deflated using a consumer price index and the many sources of bias in the consumer price index have been emphasized by the Boskin Commission (Boskin et al. 1998). Real income does not account for such goods as health that are not purchased in the marketplace, for quality changes, for revolutionary technological change, and for increases in leisure. Trends in health suggest that we may be overestimating income increases in the nineteenth century and underestimating income increases in the twentieth (Costa and Steckel 1997). Cutler et al. (1998) find that between 1983 and 1994 the price of heart attack treatments fell by 1.1 percent per year, once adjustments are made for quality, whereas a conventional price index suggests that prices were increasing. Nordhaus (1997) finds that between 1800 and 1992 the bias in a conventional price index of lighting is 3.6 percent per year. Trends in work hours imply that we are underestimating improvements in living standards during the twentieth century. Between 1890 and 1940 the average work week fell by 20 hours and retirement rates of men older than 64 rose by almost 30 percentage points (Series D 29-41, D 765-778, and D 802-810 in US Bureau of the Census 1975: 132, 168, 169). After 1940, paid vacations, holidays, sick days, and personal leave increased and retirement rates continued to rise, while the average work week remained unchanged. ${ }^{1}$

Conventional measures of income inequality may also fail to capture trends in the inequality of well-being. Trends in work hours inequality have followed a very different pattern from trends in wage inequality. Wage inequality in the United States in 1940 was comparable to that observed in 1990, but fell during the decades of the 1940s only to rise sharply beginning in

\footnotetext{
${ }^{1}$ Although the average work week as reported in census data or in the CPS has remained unchanged, time use surveys suggest that the trend in declining hours has continued even in recent times. Among employed males aged 18 to 64 total hours of work declined by 14 percent between 1965 and 1985 and hours spent at work, including commute time and work breaks, declined by 17 percent. Although increasing participation rates among women have increased women's average paid market time, total work hours of couples still has fallen. Furthermore, it would be a mistake to exclude the long, unpaid hours women spent in housework at the turn of the century. (Estimated from Robinson (1993) and Converse and Robinson (1980). See Schor (1991) for a contrary view.)
} 
the 1970s (Goldin and Margo 1992). In contrast, over the last fifty years hours of work have been rising for the well-educated and declining for those with little schooling (Coleman and Pencavel $1993 \mathrm{a} ; 1993 \mathrm{~b}$ ) both in periods when earnings inequality has been falling and when it has been rising. ${ }^{2}$ Less is known about wage inequality and about the distribution of hours prior to 1940. The census did not have a question on hours worked and on wages. Marketing and time use surveys were relatively rare. The available data suggests that the wage structure was even wider in 1915 than in 1940 (Goldin and Katz 1999) and that at the turn of the century workers in the lowest paid decile labored a full 2 hours longer per day than workers in the top decile but that by the mid 1920s the hours distribution had become much more compressed. Now the highest wage workers put in the longest work day (Costa forthcoming).

Consumer expenditure surveys provide an alternate data source for documenting trends in living standards. As incomes rise we would expect that the budget share of such necessities as food would fall and that of such luxuries as recreation would rise. In the late 1880 s less than $2 \%$ of household expenditures were devoted to recreation. Three-quarters of the household's income went to food, shelter, and clothing. By the mid-1930s, the recreational budget share had risen to $4 \%$ and by 1991 to $6 \%$. We can therefore examine whether increases in budget shares are consistent with the observed trends in real income per capita.

Consumer expenditure surveys can also be used to document trends in the inequality of living standards. Richer households spend proportionately more on such luxury goods as recreation. The proportionately more that they spend on recreation, the greater is the concentration in recreational expenditures by income class and therefore the greater the inequality in recreational expenditures. For low income households at the beginning of the twentieth century, the "usual attitude toward any expenditure for pleasure is that it is a luxury which cannot be afforded"

\footnotetext{
${ }^{2}$ Costa (forthcoming) estimates that this shift in the distribution of hours worked accounts for approximately 26 percent of the increase in wage inequality among prime-aged males from 1972 to 1991.
} 
(More 1970: 142). By the mid-1930s, low cost recreational activities, such as motoring, movies, and the radio had already diffused throughout the population. Government invested heavily in recreational facilities; the number of public swimming pools more than tripled and the number of baseball diamonds more than doubled from 1921 to 1930 alone (Series H 849-86 U.S. Bureau of the Census 1975: 398). The favorite activities of the rich and the poor have become the same. Listening to the radio rapidly became the most popular amusement across all social classes before World War II (Komarovksy et al. 1934). Today television is. ${ }^{3}$

This paper uses consumer expenditure surveys from as far back as 1888 to investigate whether trends in recreational budget shares mirror those in per capita total expenditures and to document the trend in inequality in recreational expenditures. The findings have implications for trends in living standards and for trends in the well-being of the poor relative to the rich. An advantage of using recreational expenditure elasticities rather than expenditures on another luxury or on recreation is that the results also provide evidence on long-term trends in the inequality of work hours and leisure when little direct data are available. Abbott and Ashenfelter (1976) find substantial evidence of complementarity and substitutability between commodities and non-market time. The complementarity of recreational goods with leisure suggests that the value of leisure depends upon the goods enjoyed during leisure. Declining inequality in recreational expenditures therefore suggests that inequality in leisure time has fallen as well. An additional advantage of examining recreational expenditures is that because many new goods were introduced in this sector, I can study the effect of technological change on inequality in recreational expenditures.

I will first motivate my empirical work by discussing how inequality in recreation can

\footnotetext{
${ }^{3}$ Forty-seven percent of all time spent on recreational activities in 1985 was spent on television watching among those with household incomes of less than $\$ 15,000, \$ 15,000$ to $\$ 25,000$ and $\$ 25,000$ to $\$ 35,000$. Those earning $\$ 35,000$ or more spent 43 percent of all recreational time on television watching (calculated from Robinson 1993).
} 
be measured using expenditure elasticities and what factors might affect this inequality. Then I will discuss the early consumer expenditure surveys, examine whether Engel curves consistent with utility maximization can be derived for over a century of consumer expenditure surveys (and hence whether a representative consumer analysis can be used), and present empirical estimates of expenditure elasticities from 1888 to 1991. I will also determine whether the observed pattern in expenditure elasticities can be explained by rising incomes, innovations in recreational goods (particularly the diffusion of new technologies), shifts from market to non-market forms of recreation, and falling hours of work. I will conclude by comparing the increase in real total expenditures per capita needed to achieve the observed increases in recreational budget shares, given the estimated Engel curves, with the actual increase in real total expenditures per capita.

\section{Recreation and Living Standards}

The use of commodities to measure living standards dates to Engel's observation that for identical households as income rises the share of expenditures spent on such necessities as food declines. The iso-prop method applies Engel's method to any subset of commodities to compare living standards across households. Either necessities or such luxury goods as recreation are chosen as reference goods. If any household's expenditure share on the chosen good matches the expenditure share of a reference household then the members of both households are considered to be equally well off provided that they face the same prices. ${ }^{4}$ The iso-prop method has been used to assess increases in real income when real income may be poorly measured under the assumption that the shape of the Engel curve for the given good has remained similar over time and that aggregation is satisfied (Nakamura 1997; Hamilton 1998). Provided that aggregation is satisfied, changes in

\footnotetext{
${ }^{4}$ See Blackorby and Donaldson (1994) for a closed form characterization of the requisite utility functions in terms of the expenditure function.
} 
the mean share of expenditures devoted to recreation will be an indicator of changes in per capita real total income.

Changes in the shape of Engel curves convey valuable information about trends in the distribution of well-being. Richer households spend proportionately more on a luxury good such as recreation and therefore have larger per capita recreational expenditures relative to poorer households. Declines in the expenditure elasticity of recreation, a summary measure of the shape of the Engel curve, therefore imply that the consumption of recreation has become less concentrated by income class. ${ }^{5}$

Several factors could explain declines in the expenditure elasticity of recreation. Rising incomes might lead all individuals to be located on the flatter part of the income expansion path. Technological advances have not only lowered the price of existing products, but also created new products that lower the quality-adjusted price of entertainment, such as listening to a piece of music or watching a comic skit, and that have increased demand for recreation. They have also lowered the time cost of entertainment by lowering travel time. In addition, the public provision of such recreational goods as parks has lowered the cost of such complementary goods as sporting equipment. As recreational goods become more affordable, poorer households may consume more of them. Recreational expenditure elasticities could decline if poorer households disproportionately shift from non-market to market recreational goods. Increases in the hours of work of richer households relative to poorer households would lead richer households to consume fewer recreational goods relative to poorer households provided that leisure and recreational goods are complements.

\footnotetext{
${ }^{5}$ The Appendix shows trends in expenditure elasticities of other commodities. Although the expenditure elasticities of specific commodity groups have fluctuated, there has been relatively little change in the expenditure elasticity of all goods other than recreation.
} 


\section{Consumer Expenditure Surveys}

In 1888 the United States Department of Labor undertook the first nationwide consumer expenditure survey. Although the purposes of subsequent surveys (such as those carried out in 1917-1919, 1934-1936, 1935-1936, 1950, 1972-1973, and 1991) differed and somewhat different populations were represented, the surveys are generally comparable. All provided a thorough accounting of family sources of income and outlays of that income and thus were extensively checked for completeness and consistency. All utilized roughly similar interview techniques - multiple visits, strong encouragement to keep written records, and the use of home surroundings to stimulate accurate recall of expenditure data. All used schedules that strongly resembled each other. And, trends in the budget shares of most broad categories of goods in all of the surveys are consistent with the national income and product accounts. ${ }^{6}$

Although the surveys represent different populations, it is possible to restrict the later surveys to make them more comparable to the early surveys. I do this and I also present results from the full samples for comparison. The range of total expenditures is always greater in the later surveys than in the earlier surveys. Therefore, if expenditure elasticities begin to fall at higher expenditure levels, I may be overestimating inequality in recreational consumption in the early surveys. If expenditure elasticities begin to rise at higher expenditure levels then I will be underestimating. But, provided that I can compare expenditure elasticities at different percentiles, I will be able to bound the change in expenditure elasticities.

The surveys used in this paper and described in the rest of this section are the Department of Labor's Cost of Living of Industrial Workers in the United States and Europe, 1888-1890; the Bureau of Labor Statistics' Cost of Living in the United States, 1917-1919; the Department of Labor and the Department of Agriculture's Study of Consumer Purchases in the United States,

\footnotetext{
${ }^{6}$ See Tables 1 and 2. Food between 1935 and 1950 is an exception.
} 
1935-1936; the Survey of Consumer Expenditures, 1972-1973; and the 1991 Consumer Expenditure Survey. ${ }^{7}$ With the exception of 1991, when five quarters of data are provided, all data are annual.

In 1888-1890 the sample was limited to workers in nine protected industries (bar iron, pig iron, steel, bituminous coal, coke, iron ore, cotton textiles, woolens, and glass) and appears to have been stratified by the proportions employed in each industry. Twenty-three states were covered, none of them in the west. Sample families were selected from employer records and were limited to families of two or more persons. For greater comparability with the 1917-1919 and 1935-1936 surveys the sample was restricted to husband and wife families. ${ }^{8}$ Total sample size is 6,716 .

Families from the 1917-1919 study were also selected from employer records and were restricted to those where both spouses and one or more children were present, where salaried workers did not earn more than $\$ 2,000$ a year $(\$ 20,400$ in 1990 dollars), where families had resided in the same community for a year prior to the survey, where families did not take in more than three boarders, where families were not classified as either slum or charity, and where non-English speaking families had been in the United States five or more years. Ninety-nine cities in 42 states were covered. The sample contains 12,817 families, 849 of whom were black.

Two expenditure surveys were carried out in the 1930s. One was the 1934-1936 Survey of Money Disbursements of Wage and Clerical Workers. This survey was restricted to wage earners and clerical workers earning less than $\$ 2,000$ per year in large urban areas of the United States and families in which the chief earner earned at least $\$ 300$. This survey is not available in

\footnotetext{
${ }^{7}$ The micro data for the 1888-1890, 1917-1919, 1935-1936, and 1972-1973 surveys were obtained from ICPSR (ICPSR Study Numbers 7711, 8299, 8908, and 9034).

${ }^{8}$ Since relatively few sample households were not husband and wife families the results remain unchanged when the entire sample is used.
} 
machine readable form. The second survey was the 1935-1936 Consumer Purchases Study which was limited to native-born husband and wife families in which families in metropolises and white families in large cities had a minimum income of at least $\$ 500(\$ 4,800$ in 1990 dollars $)$ and families in other cities one of at least $\$ 250$ (\$2,400 in 1990 dollars). There was no upper income limit. The survey covered self-employed workers as well as wage and salary workers. The communities covered by the study included 51 cities, 140 villages and 60 farm counties, representing 30 states. Consumption data was collected for approximately 60,000 families. Random subsamples of the urban and rural samples are available in machine readable form. The urban sample contains 3,062 families with usable expenditure data (182 of whom were black) and the rural sample 2,902 families (321 of whom were black). The urban sample covered families in cities of at least 8,000 and the rural sample families in villages of 500 to 3,200 as well as farm families.

The next major consumer expenditure survey was in 1950 and covered wage-earner and clerical families in cities of 2,500 or more. The only income restriction was the exclusion of families whose total income after taxes exceeded $\$ 10,000$. This survey is not available in machine readable form. ${ }^{9}$

By 1972 the consumer expenditure surveys were representative of the entire population. Although five quarters of data are given for 1991, covering the end of 1990, 1991, and the beginning of 1992, only the second quarter of data was used in regression estimates. ${ }^{10}$ To ensure an age and income distribution more comparable to that in the 1917-1919 survey, results are presented in which families found in the 1972-1973 and 1991 Consumer Expenditure Surveys were restricted to husband and wife families above the poverty line in which at least one spouse

\footnotetext{
${ }^{9}$ For more details about the coverage and methodology of the 1888-1890, 1917-1919, 1934-1936, 1935-1936, and 1950 surveys, see Lamale (1959).

${ }^{10}$ Some households were interviewed for more than a quarter. The results remain unchanged when another quarter of data is used.
} 
was employed and in which the husband was less than 65.

The 1935-1936 survey was the first in which a subsample of the interviewed population was asked to keep a detailed diary of such expenditures as food, household supplies, and personal care items for a week. Such diaries were kept in 1972 and 1991 as well. However, I use only the interview survey because it is likely to be more comparable to the earlier surveys.

The questions asked about spending on specific recreational items varied by survey. Only two questions were asked about recreational expenditures in 1888-1890. One was about expenditures on books and newspapers and the other was about expenditures on the broad category of amusements and vacations. By 1917 families were already asked a much richer set of questions, including the total cost of purchased musical instruments, records, and rolls for player pianos and organs and of toys, sleds, and carts, and the individual cost of movies, plays, dances, pool, excursions, vacations, books, and newspapers. Changes in recreational activities led to a different set of questions being asked in 1935-36 when households were queried about family expenditures on books; newspapers; games or sports equipment; radio purchases and maintenance; musical instruments; movies; plays, concerts, and lectures; spectator sports; dances, circuses, and fairs; sheet music and records; photographic equipment; toys; pets; entertainment, and social and recreational club dues. By 1972 the individual categories become too extensive to itemize, ranging from country club memberships to electrical equipment to music lessons to swimming pool maintenance. Vacation expenditures on food, lodging, and travel are explicitly identified as are expenditures on vacation homes. However, by 1991 vacation expenditures on food, lodging, and gasoline are no longer identified. Because vacation travel was identified in neither the 19351936 nor the 1991 surveys, I do not include it in total recreational expenditures in 1972-1973. I will, however, present two estimates of expenditure elasticities for 1917-1919, with and without vacation expenditures. As in previous years, I include reading as a recreational expenditure in both 1972-1973 and 1991. 


\section{Trends}

Table 1 illustrates the trend in recreation and in other expenditures since $1888 .{ }^{11}$ The share of household expenditures devoted to recreation rose from less than 2 percent in 1888 to 3 percent in 1917, 4 percent in the mid-1930s, 5 percent in 1950, and 6 percent in 1991. Although recreational expenditures may be overestimated in all surveys because not all reading is for entertainment, the increase in recreational budget share since 1917-1919 is probably underestimated because earlier definitions of recreation included the amount spent on vacations and excursions, but travel and lodging is not included in the 1934-1936, 1935-1936, 1950, 1972-1973, and 1991 definitions of recreational expenses. In 1935-1936 approximately 2 percent of the budget share of housing expenditures went to vacation home rentals, purchase, and upkeep. No information is available on the share of travel expenditures devoted to recreation. In 1972-1973, at least 5 percent of the budget share of travel and shelter went to vacation lodging and travel. When vacation expenses are included in the definition of recreation in 1972-1973 the budget share devoted to recreation rises to 6.8 percent. Assuming that 5 percent of the budget share of travel and shelter went to vacation lodging and travel in 1991 as well and including expenditures on vacation homes, then the budget share of recreation rises to 7.9 percent in 1991. Table 1 will underestimate recreational expenditures because the recreational budget share does not include payment for such public goods as parks. Table 1 will also underestimate recreational expenditures because the time cost of recreation is the largest expense. The full share of recreational expenditures (the monetary and the time costs) was approximately 16 percent of the total budget in 1991 and was at most 9

\footnotetext{
${ }^{11}$ The published Bureau of Labor Statistics tables which combine the interview and diary surveys yield somewhat different numbers in 1972-1973 and 1991. They suggest that the share of recreation was higher in both years and that the share of food was lower in 1991.
} 
Table 1: Budget Shares for Specific Items, Consumer Expenditure Surveys, 1888-1991

\begin{tabular}{lrrrrrrrr}
\hline & $1888-$ & $1917-$ & $1934-$ & \multicolumn{1}{c}{$1935-1936$} & \multicolumn{3}{c}{$1972-$} \\
Item's budget share (\%) & 1890 & 1919 & 1936 & urban & rural & 1950 & 1973 & 1991 \\
\hline Food & 44.5 & 39.2 & 34.7 & 31.9 & 32.9 & 30.7 & 25.8 & 21.0 \\
$\quad$ Food at home & & 38.2 & 31.5 & 28.8 & 31.4 & 24.8 & 18.5 & 12.7 \\
Shelter & 13.7 & 13.6 & 17.7 & 15.0 & 6.6 & 10.6 & 19.2 & 19.1 \\
Apparel & 16.7 & 16.2 & 10.9 & 9.7 & 12.7 & 11.5 & 6.0 & 4.7 \\
Utilities & 6.0 & 5.4 & 7.4 & 7.2 & 7.1 & 4.2 & 6.2 & 9.8 \\
Furniture and equipment & 3.2 & 3.9 & 4.1 & 2.4 & 2.9 & 7.1 & 4.0 & 3.0 \\
Transportation & & 3.0 & 8.5 & 9.5 & 12.5 & 13.8 & 19.5 & 18.9 \\
Health & 3.3 & 4.5 & 4.0 & 4.7 & 5.9 & 5.1 & 6.1 & 7.0 \\
Education & & 0.4 & 0.5 & 0.8 & 1.0 & 0.4 & 0.8 & 1.3 \\
Recreation & 1.9 & 3.2 & 3.5 & 4.2 & 3.8 & 4.5 & 4.8 & 5.5 \\
Other & 10.7 & 10.6 & 8.7 & 14.6 & 14.6 & 12.1 & 7.5 & 12.9 \\
Total expenditures & & & & & & & & \\
(1982-1984=100) & 6,105 & 11,086 & 10,679 & 14,605 & 7,810 & 16,286 & 21,230 & 21,743 \\
Average family size & 3.9 & 4.9 & 3.6 & 3.7 & 3.8 & 3.4 & 3.0 & 2.6 \\
Number of observations & 6,716 & 12,817 & 14,469 & 3,062 & 2,902 & 7,007 & 19,975 & 15,335 \\
\hline
\end{tabular}

Note. Estimated from Cost of Living of Industrial Workers in the United States and Europe, 1888-1890 (ICPSR 7711); Cost of Living in the United States, 1917-1919 (ICPSR 8299); Survey of Money Disbursements of Wage and Clerical Workers, 1934-1936, covering families of employed workers in cities of 50,000 or more (United States Department of Labor 1939); Study of Consumer Purchases in the United States, 1935-1936 (ICPSR 8908) covering employed wage and salary and self-employed workers in urban and rural areas; Study of Consumer Expenditures, Incomes and Savings, 1950 covering wage-earner and clerical worker families in cities of 2,500 or more (Bureau of Labor Statistics 1956); Survey of Consumer Expenditures, 1972-1973; and four quarters of Consumer Expenditure Survey, 1991. Reading materials are included in the recreation budget share. The shelter category includes only rent in 1888-1890. The 1972-1973 and 1991 surveys were representative of the entire population whereas the earlier surveys were not. The population in the 1934-1936 urban survey more closely resembles that of 1917-1919 than of recent surveys (see text). In contrast, the population of the 1935-1936 survey more closely resembles that of recent surveys. The 1972-1973 and 1991 figures differ from those given in Bureau of Labor Statistics publications because they are based on interview surveys rather than a combination of interview and diary surveys. The 1972-1973 figures also differ because such items as food eaten on vacation were included as a food rather than as a recreational expense. Contributions to pensions and Social Security are counted as savings and excluded from the total expenditures in 1972 and in 1991 (see text). I would like to thank Peter Lindert for the use of his consumer price index. 
Table 2: Budget Shares for Specific Items, National Income and Product Accounts, 1919-1991

\begin{tabular}{lrrrrr}
\hline Item's budget share (\%) & 1919 & 1935 & 1950 & 1972 & 1991 \\
\hline Food & 33.9 & 28.9 & 31.5 & 20.7 & 16.0 \\
$\quad$ Food at home & & 23.4 & 24.6 & 15.0 & 10.5 \\
Shelter & 13.3 & 13.5 & 10.4 & 14.5 & 14.8 \\
Apparel & 14.8 & 12.1 & 11.7 & 7.3 & 6.1 \\
Utilities & 3.6 & 5.0 & 2.6 & 3.4 & 3.9 \\
Furniture and equipment & 5.3 & 5.0 & 6.4 & 4.9 & 3.0 \\
Transportation & 8.1 & 9.6 & 12.1 & 13.7 & 11.6 \\
Health & 3.4 & 4.1 & 4.3 & 9.7 & 15.3 \\
Education & 1.2 & 1.6 & 1.5 & 2.0 & 2.3 \\
Recreation & 3.6 & 4.0 & 5.3 & 6.7 & 8.0 \\
Other & 12.8 & 16.2 & 14.2 & 17.1 & 20.0 \\
Per capita & & & & & \\
expenditures & 3289 & 3225 & 5301 & 8297 & 11,355 \\
(1982-1984=100) & & & & & \\
\hline
\end{tabular}

Note. Estimated from Dewhurst and Associates (1955) and the unpublished, detailed national income and product accounts on http://www.stat-usa.gov/.

percent in $1910 .^{12}$

Table 2 shows budget shares from the national income and product accounts for the same years as the consumer expenditure surveys beginning with $1919 .{ }^{13}$ Note that the national income and product accounts suggest that trends in national budget shares between 1919 and 1935 may be most accurately captured by comparing the 1917-1919 consumer expenditure survey with the 1934-1936 survey. ${ }^{14}$

\footnotetext{
${ }^{12}$ In 1985 approximately 22 percent of all time in a single day was devoted to leisure (estimated from Robinson (1993)). Assuming that full expenditures are equal to the sum of all yearly expenditures and the product of yearly hours and the average hourly wage of manufacturing workers, the share of full expenditures is equal to 16 percent. The real wage has tripled since the 1910s. If at least 11 percent of all time in 1910 was devoted to leisure then the budget share then the full budget share of recreation is 9 percent. This is likely to be a lower bound estimate. Fogel (1999) estimates that circa 1880 only 7 percent of all time was devoted to leisure.

${ }^{13}$ Estimates prior to 1909 do not exist.

${ }^{14}$ In fact, a comparison of occupations with those in the census suggests that the 1917-1919 population more closely resembles that of the 1934-1936 survey than that of the 1935-1936 survey.
} 
Table 3: Changes in the Recreational Budget, Consumer Expenditure Survey, 1888-1991

\begin{tabular}{|c|c|c|c|c|c|c|c|c|}
\hline year & $\begin{array}{c}\text { reading } \\
\text { materials }\end{array}$ & $\begin{array}{l}\text { Perce } \\
\text { movies and } \\
\text { live enter- } \\
\text { tainment }\end{array}$ & $\begin{array}{l}\text { Recreati } \\
\text { home } \\
\text { enter- } \\
\text { tainment }\end{array}$ & $\begin{array}{c}\text { nal Expen } \\
\text { sporting } \\
\text { equip- } \\
\text { ment }\end{array}$ & ditures & pent & $\begin{array}{l}\text { photo- } \\
\text { graphy }\end{array}$ & $\begin{array}{c}\text { vacations } \\
\text { and ex- } \\
\text { cursions }\end{array}$ \\
\hline 1888-1890 & 65.3 & & & & & & & \\
\hline $1917-1919$ & 38.9 & 22.9 & 10.4 & & 8.4 & 16.5 & & \\
\hline $1935-1936$ & & & & & & & & \\
\hline urban & 34.3 & 29.9 & 7.6 & 6.8 & 6.0 & 6.4 & 1.4 & \\
\hline rural & 37.7 & 24.6 & 11.2 & 7.3 & 4.2 & 8.5 & 1.3 & \\
\hline $1972-1973$ & 21.0 & 15.3 & 30.4 & 7.0 & 7.2 & 1.9 & 8.3 & \\
\hline 1991 & 13.3 & 5.7 & 27.1 & 4.4 & 4.2 & 7.2 & 3.4 & \\
\hline $1917-1919$ & 34.0 & 20.0 & 9.7 & & 7.4 & 14.5 & & 11.8 \\
\hline $1972-1973$ & 15.2 & 10.5 & 24.0 & 5.2 & 4.9 & 1.5 & 5.6 & 27.4 \\
\hline
\end{tabular}

Note. Home entertainment includes expenditures on musical instruments, sheet music, movie rentals, cable television and the purchase, repair, or rental of radios, television, stereos, and videocassette recorders. The recreational budget share of toys in 1991 is probably overestimated and that of photography underestimated relative to 1972-1973 because of slight differences in classifications of specific items. Expenditures on vacations and excursions are included in the definition of recreation in the last two rows and in the 1888-1890 survey. The 1972-1973 and 1991 surveys were representative of the entire population, whereas the earlier surveys were not (see text).

Trends in the percentage of recreational expenditures devoted to seven broad recreational categories in the consumer expenditure survey are described in Table 3. The share of reading has fallen from 65 percent in 1888 to 39 percent in 1917 and in 1991 stood at 13 percent. The share of movies and live entertainment fell from 21 percent in 1917 to 6 percent in 1991. The share of recreational expenditures providing either listening or viewing pleasure in the home (everything from musical instruments to television) rose from 10 percent in 1917 to 27 percent by 1991 . In contrast, recreational expenditures on sporting equipment have fallen from 7 to 4 percent between 1935 and 1991 and on clubs from 8 to 4 percent between 1917 and 1991. The recreational budget share of toys and of photography has fluctuated somewhat (the specific categories are not fully comparable), but over the long run that of toys has fallen and that of photography has risen.

The budget share of recreation increased across all years despite fluctuations in the 
relative price of recreation (see Figure 1). Between 1901 and 1919 the relative price of recreation fell by 20 percent, because of declines in the relative price of cameras, musical instruments, records, and sheet music, and then by another 18 percent between 1919 and 1935, with the sharpest decline in the relative price of radios. The relative price of recreation then increased by 23 percent between 1935 and 1950, largely because of increases in the relative price of the radio, television, and phonograph sector, and by another 7 percent between 1950 and 1972. Between 1972 and 1991 the relative price declined by 7 percent. These fluctuations in the relative price of recreation led to a fairly constant price between the years 1919 and 1950 and 1950 and 1991.

Tables 1 and 2 show that trends in real income do not always correspond to trends in well-being as measured by the budget share devoted to recreation or to food. Between 1919 and 1935 real expenditures per capita fell, but the share of recreation increased and the share of food fell. ${ }^{15}$ Although both the relative price of food and of recreation fell in this time period, they fell by similar percentages. Furthermore, because the price of recreation fell increases in the quantity of recreational goods purchased are underestimated. Real total household expenditures stagnated between 1972 and 1991 and per capita expenditures grew only 1.8 percent per year between 1972 and 1991, but the food share fell and the recreational share increased. These aggregate numbers, however, will only be indicators of rising per capita expenditures, if aggregation holds. Furthermore, these aggregate numbers may be deceptive indicators of well-being if recreational expenditures increased only for individuals in the top of the income distribution. I therefore turn to the estimation of Engel curves.

\footnotetext{
${ }^{15}$ Although the decline in the share of food eaten at home may be attributable to declining fertility, the increase in the share of recreation cannot. Estimated budget share equations suggest that the decline in the number of children should have decreased recreational expenditures. Note that well-being may be overestimated because the consumer surveys were restricted to the employed and the national income and product accounts do not account for the much greater risk of unemployment in 1935 than in 1919.
} 
Figure 1: Relative Price of Recreation, 1901-1991

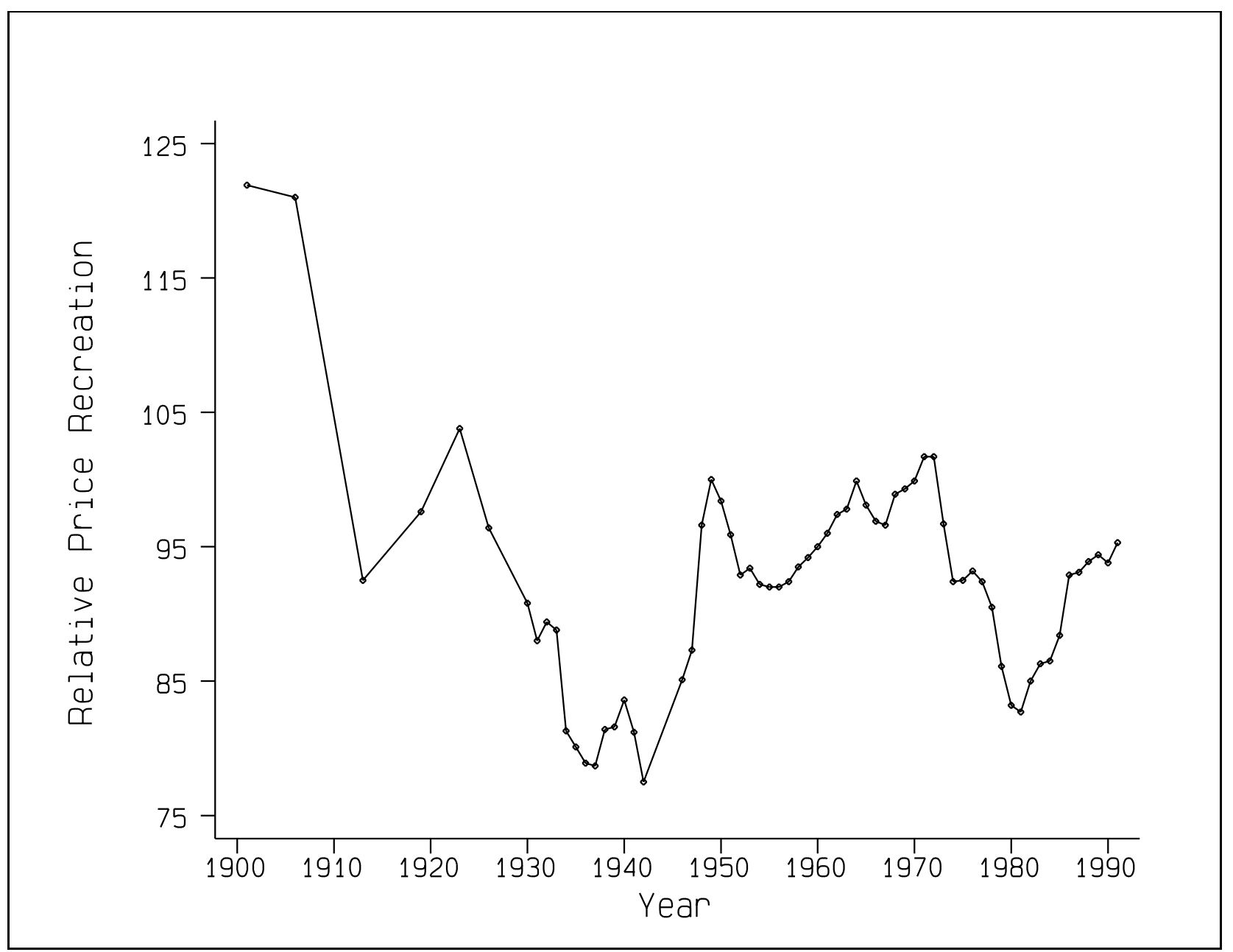

Note. The relative price of recreation is defined as the ratio of the price of recreation to the price of all goods. The series is constructed from Owen (1969) for 1901-1961, from Series E 135-166 in U.S. Bureau of the Census (1975: 210) for 1962 to 1967, and from U.S. Bureau of Labor Statistics (1998: 263) for 1968 to 1991. 


\section{Specifying Engel Curves}

Figures 2 and 3 give nonparametric descriptions of the relationship between recreational budget shares and total expenditures for white, urban husband and wife households in which the husband was employed and was below age $65 .{ }^{16}$ Note that the nonparametric regressions suggest that curvature in Engel curves increased from the end of the last century to the mid-1930s, leading to a flattening of the relationship between total expenditures and the share of recreation. This curvature in Engel curves is unlikely to be captured by the most common parametric form which relates budget shares linearly to the logarithm of expenditures,

$$
w=\alpha+\beta \log (z)
$$

where $w$ is the budget share and $\alpha$ and $\beta$ are parameters to be estimated. The nonparametric regressions therefore suggest that this simple specification should be generalized to higher order terms. Recent work suggests this as well (Hausman et et al. 1995; Banks et al. 1997). I use the form

$$
w=\alpha+\beta_{1} \log (z)+\beta_{2} \log ^{2}(z)+\beta_{3} \log ^{3}(z) .
$$

A quadratic polynomial specification yields fairly similar curves to the cubic, except for the tails where the data are very sparse, but because the cubic term was statistically significant in the specifications that I ran, I use the cubic specification. ${ }^{17}$

Figures 4 and 5 compare the kernel regression with the cubic polynomial specification.

\footnotetext{
${ }^{16}$ The data were restricted to relatively homogenous subsamples to assess the shape of the Engel curves.

${ }^{17} \mathrm{My}$ overall findings remain unchanged if I use a quadratic specification. Terms higher than a cubic were not statistically significant.
} 
Figure 2: Nonparametric Engel Curves (Estimated from Kernel Regressions), 1888-1936

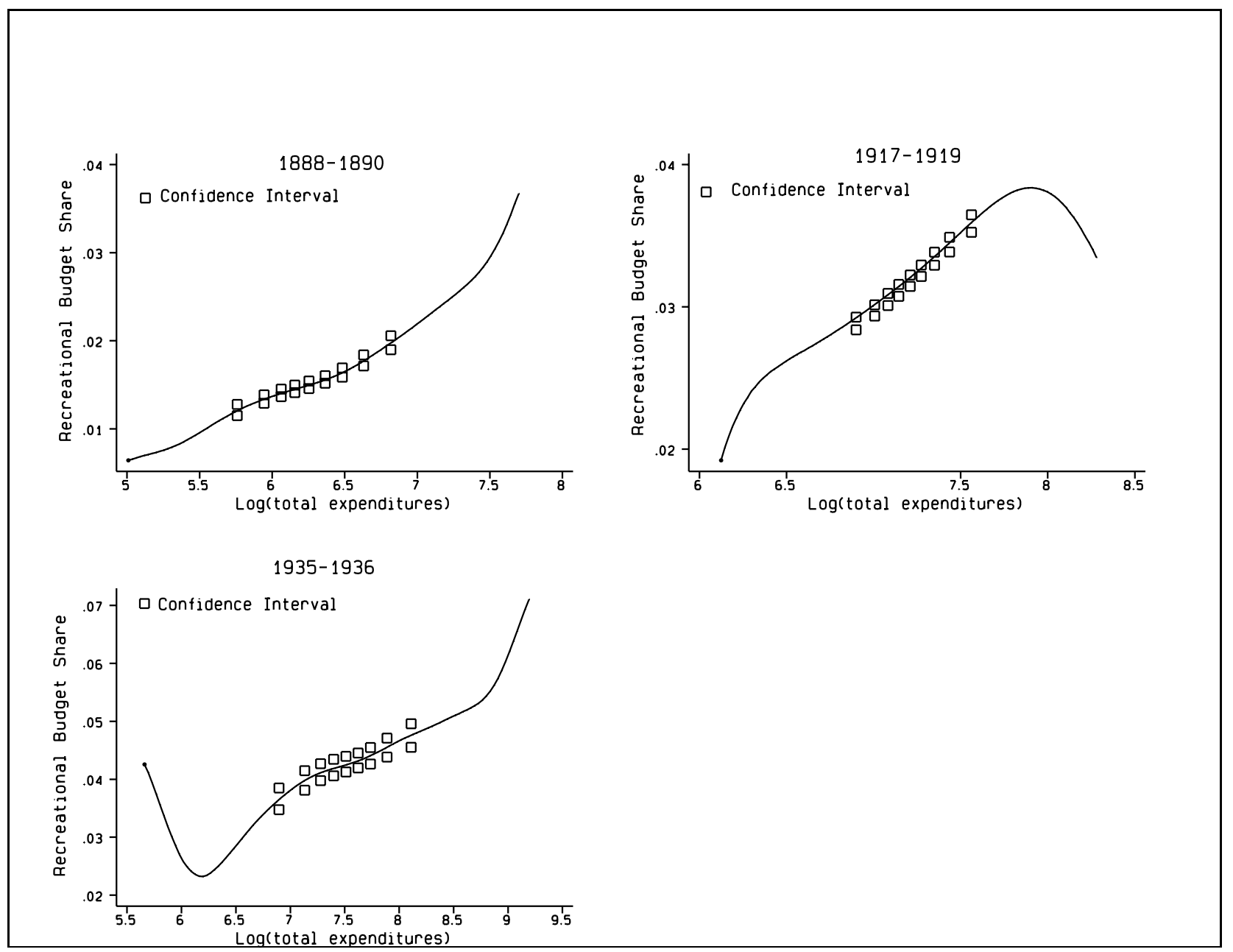

Note. All kernel regressions use a Gaussian kernel and the Nadaraya-Watson kernel smoother with a bandwidth of 0.2 (Härdle 1991: 25, 147-189). Ninety percent pointwise bootstrap confidence intevals are evaluated at the expenditure deciles. The samples were restricted to white, urban husband and wife households in which the husband was employed and was below age 65 . 
Figure 3: Nonparametric Engel Curves (Estimated from Kernel Regressions), 1972-1991

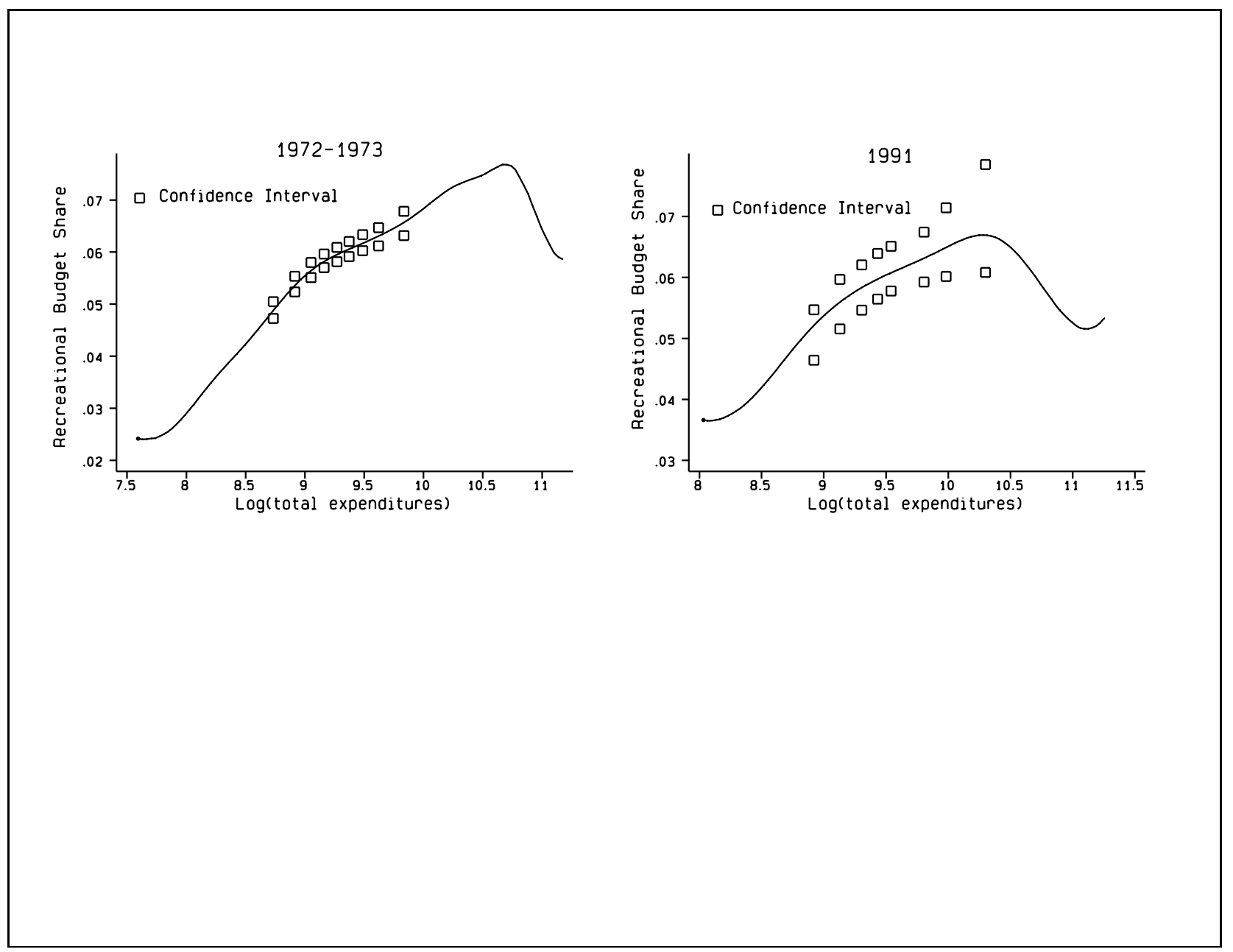

Note. All kernel regressions use a Gaussian kernel and the Nadaraya-Watson kernel smoother with a bandwidth of 0.2 (Härdle 1991: 25, 147-189). Ninety percent pointwise bootstrap confidence intevals are evaluated at the expenditure deciles. The samples were restricted to white, urban husband and wife households in which the husband was employed and was below age 65 . 
The polynomial specification estimates the nonparametric regression at the 50th percentile very well in all years, and with the exception of 1917 , at the 25 th and 75 th percentiles as well. However, the polynomial specification does deviate from the kernel regression at the tails where there are little data, as would be expected.

Engel curves that contain a cubic term in income are consistent with utility maximization only if the matrix of coefficients linking each demand to each power of income does not have rank greater than three (Gorman 1981). For Engel curves of polynomial degree three the rank restriction takes the form that the ratio of the coefficient of the quadratic term to the coefficient of the cubic term will be constant across budget share equations (Hausman et al. 1995). Only if these ratios are constant across budget share equations can Engel curve demands be exactly aggregated across individuals having different income levels.

Table 4 reports the ratio of $\beta_{2}$ to $\beta_{3}$ for the main budget categories. Except for a few cases where the standard error is large, the ratios within each year are similar across expenditure categories, suggesting that the Gorman rank condition is satisfied. I can therefore use estimated Engel curves to analyze trends in living standards using the consumption data in Table 2.

\section{Less of a Luxury}

I estimate expenditure elasticities for recreation using equation 3 and equation 3 modified to include such demographic variables as age and age squared of the husband to account for life cycle effects and the number of children and the number of children squared to account for differences in household size. ${ }^{18}$ Although total expenditure is likely to be measured with error

\footnotetext{
${ }^{18}$ I tested for robustness to potential omitted variables using the recent data. Although the recreational share was negatively, but insignificantly, related to total hours worked by the husband and wife, the inclusion of hours worked did not affect the estimated expenditure elasticities. Elasticities estimated for families with and without children and for families where the household head was above and below age 65 were very similar.
} 
Figure 4: Nonparametric (Estimated from Kernel Regressions) and Parametric (Cubic Polynomial) Engel Curves, 1888-1936

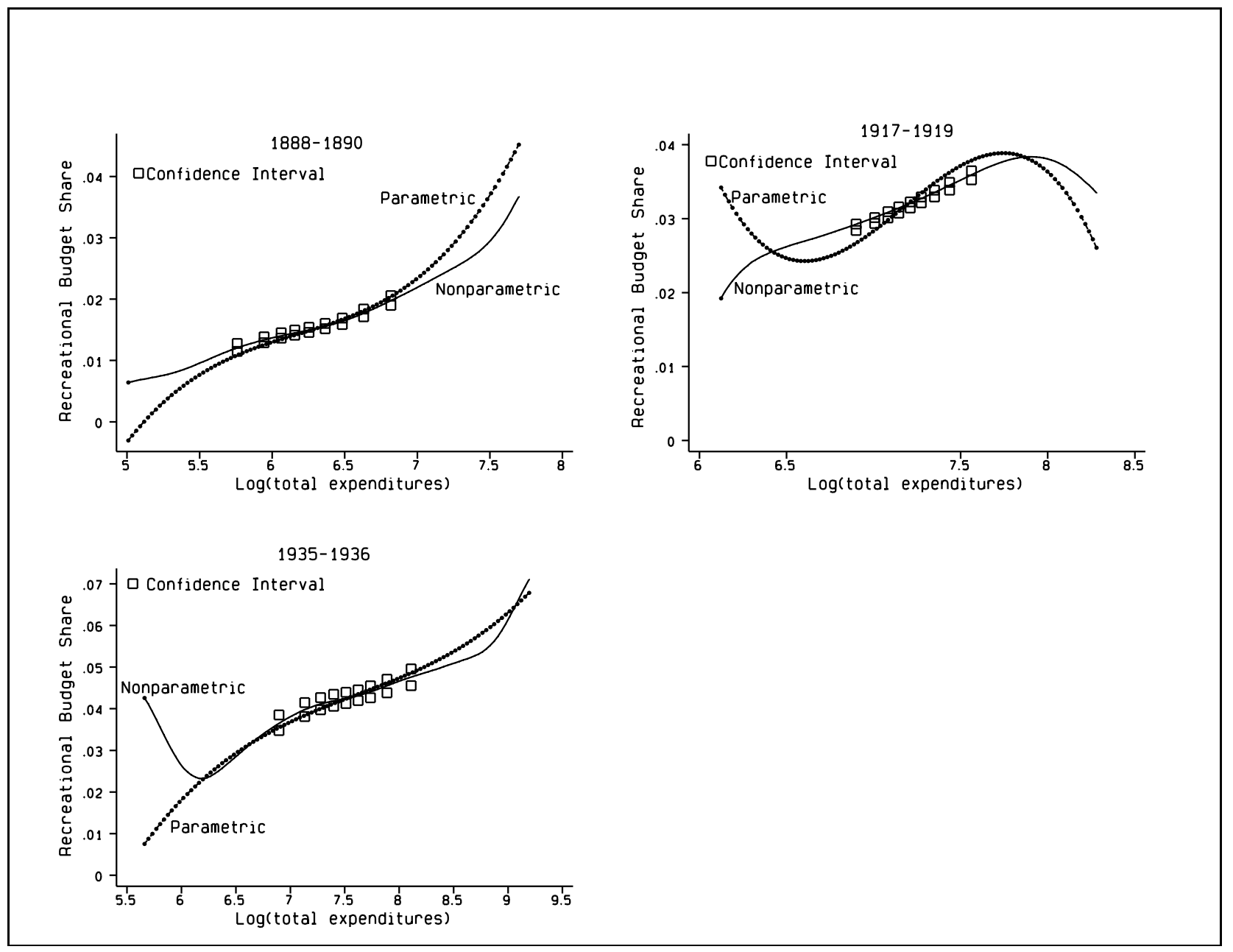

Note. All kernel regressions use a Gaussian kernel and the Nadaraya-Watson kernel smoother with a bandwidth of 0.2 (Härdle 1991: 25, 147-189). Ninety percent pointwise bootstrap confidence intevals are evaluated at the expenditure deciles. The samples were restricted to white, urban husband and wife households in which the husband was employed and was below age 65 . 
Figure 5: Nonparametric (Estimated from Kernel Regressions) and Parametric (Cubic Polynomial) Engel Curves, 1972-1991

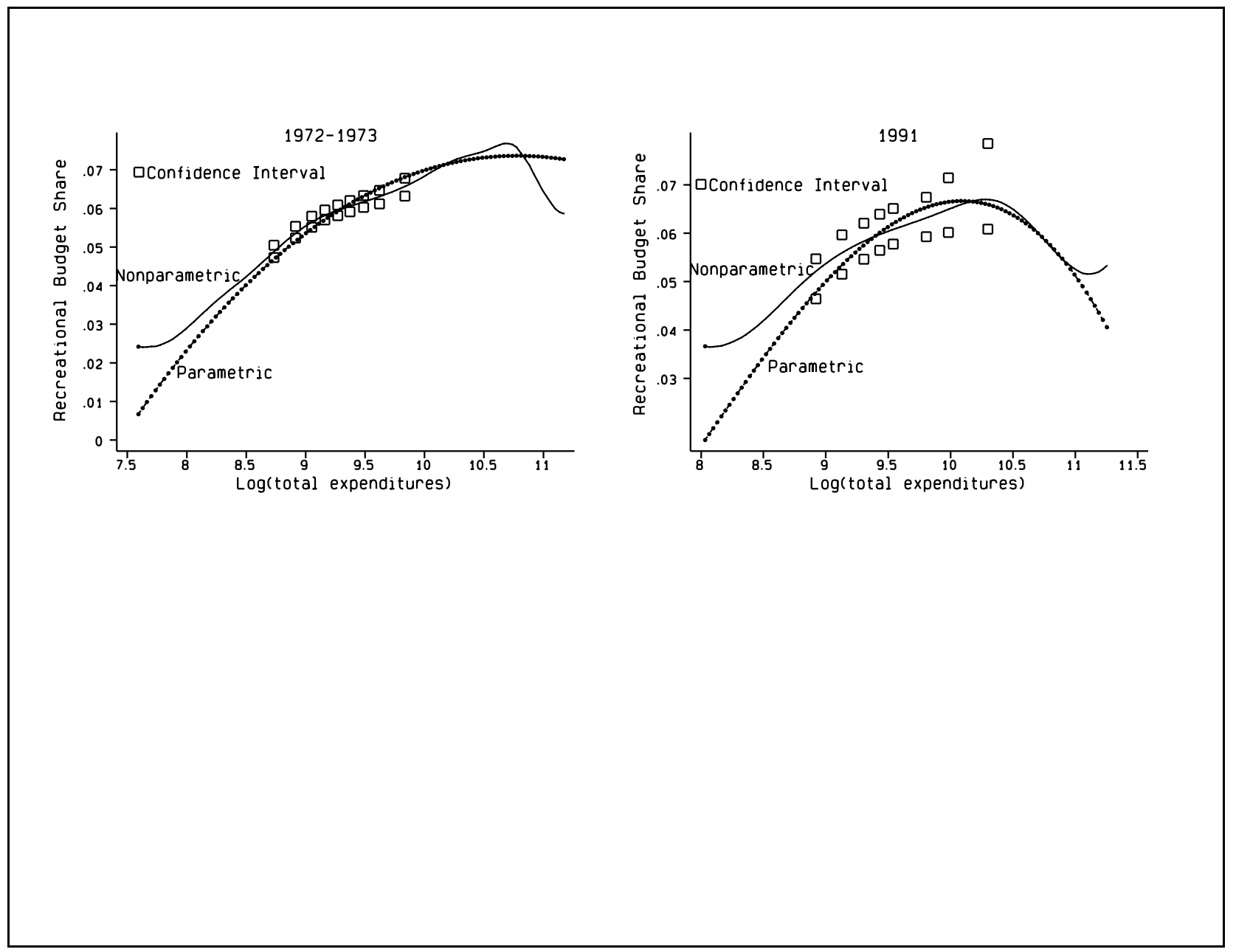

Note. All kernel regressions use a Gaussian kernel and the Nadaraya-Watson kernel smoother with a bandwidth of 0.2 (Härdle 1991: 25, 147-189). Ninety percent pointwise bootstrap confidence intevals are evaluated at the expenditure deciles. The samples were restricted to white, urban husband and wife households in which the husband was employed and was below age 65 . 
Table 4: Ratio of $\beta_{2}$ to $\beta_{3}$

\begin{tabular}{lcccccc}
\hline & $1888-$ & $1917-$ & \multicolumn{2}{c}{$1935-1936$} & $1972-$ & \\
& 1890 & 1919 & urban & rural & 1973 & 1991 \\
\hline Food & -18.478 & -20.979 & -22.719 & -17.824 & -27.981 & -25.612 \\
& $(0.265)$ & $(0.430)$ & $(0.729)$ & $(0.863)$ & $(1.522)$ & $(1.526)$ \\
Shelter & & -21.595 & -22.896 & -19.313 & -26.292 & 62.057 \\
& & $(0.078)$ & $(0.528)$ & $(0.233)$ & $(0.162)$ & $(551.969)$ \\
Apparel & -18.741 & -20.262 & -20.561 & -16.456 & -25.973 & -27.605 \\
& $(0.692)$ & $(0.850)$ & $(3.246)$ & $(1.134)$ & $(0.119)$ & $(0.162)$ \\
Utilities & -20.772 & -21.705 & -22.256 & -15.103 & -25.162 & -28.015 \\
& $(1.621)$ & $(0.292)$ & $(0.387)$ & $(1.626)$ & $(0.137)$ & $(0.207)$ \\
Furniture and equipment & 27.402 & -20.953 & -22.228 & -27.046 & -24.252 & -26.605 \\
& $(2059.1)$ & $(0.313)$ & $(0.902)$ & $(48.706)$ & $(0.429)$ & $(0.312)$ \\
Transportation & & -24.952 & -21.552 & -19.448 & -24.707 & -24.201 \\
& & $(2.890)$ & $(0.553)$ & $(0.794)$ & $(0.145)$ & $(0.544)$ \\
Health & -83.530 & -21.278 & -22.218 & -20.139 & -26.627 & -30.676 \\
& & $(0.221)$ & $(1.169)$ & $(0.715)$ & $(0.484)$ & $(1.960)$ \\
Education & -21.969 & -20.127 & -18.460 & -17.950 & -29.451 \\
& & $(0.161)$ & $(2.260)$ & $(0.403)$ & $(2.130)$ & $(0.744)$ \\
Recreation & $-1854.688)$ & -21.430 & -22.554 & -18.834 & -26.514 & -28.888 \\
& $(0.295)$ & $(0.144)$ & $(0.346)$ & $(1.359)$ & $(0.305)$ & $(3.057)$ \\
\hline
\end{tabular}

Note. Standard errors are in parentheses. Engel curves for housing were not estimated for 1888-1890 because information is available only for renters. The estimates for 1972-1973 and 1991 are based upon the unrestricted data. 
a good instrumental variable is available only for 1991 when next quarter's expenditures can be used as an instrument for current quarter's expenditures. ${ }^{19}$ Because the resulting IV estimates of the expenditure elasticities in 1991 were reasonably close to the OLS estimates, I simply present the OLS estimates for all years.

Table 5 shows that there has been a sharp decline in expenditure elasticities since the beginning of the century. ${ }^{20}$ Expenditure elasticities ranged from about two or greater at the beginning of the century but fell to a bit more than one by the mid-1930s. Although elasticities increased slightly between 1935-1936 and 1972-1973, they fell between 1972-1973 and 1991. Elasticities in 1935-1936 were lower in the rural than in the urban sample. Demographic variables exerted a significant influence on expenditure shares in all years, but the expenditure elasticities are affected mainly in the early years (upwards). When elasticities are evaluated at the 1972 demographic means, expenditure elasticities fall somewhat in 1888-1890, but the long-term trend remains unchanged: expenditure elasticities fall from 2.1 in 1888-1890 to 1.4 in 1991. Expenditure elasticities in 1991 were even lower when no restrictions were imposed on the data. I rejected the hypothesis that any year-wise pairs of elasticities evaluated at the 50th percentile were equal.

I also estimated recreational expenditure elasticities under alternative definitions of recreation in which I excluded reading materials (because of the educational component), included alcohol and tobacco, included food eaten out (all adult forms of recreation), and included

\footnotetext{
${ }^{19}$ In a life-cycle model all current information about the life-time budget constraint will be incorporated into the decision on current expenditures, thereby suggesting the lagged expenditures would not be a good instrument. However, innovations in future consumption will be independent of current information. This instrument was used by Hausman et al. (1995) who found that both the IV and the OLS results accurately estimated the elasticities. Using household income as an instrumental variable, though previously used in the literature, would entail making some assumptions about the relationship between permanent and transitory income.

${ }^{20}$ The expenditure elasticity is equal to $1+\frac{\partial \hat{w}}{\partial \log (z)} \hat{w}^{-1}$, where $\hat{w}$ is predicted at one of the three quartiles. Polynomial coefficient estimates are not reported because they are relatively uninformative.
} 
Table 5: Recreation Expenditure Elasticity Estimates

\begin{tabular}{|c|c|c|c|c|c|c|c|c|c|}
\hline \multirow[b]{2}{*}{ year } & \multicolumn{3}{|c|}{$\begin{array}{l}\text { without demographic } \\
\text { variables } \\
\text { percentile }\end{array}$} & \multicolumn{3}{|c|}{$\begin{array}{l}\text { with demographic } \\
\text { variables } \\
\text { percentile }\end{array}$} & \multicolumn{3}{|c|}{$\begin{array}{c}\text { evaluated at means } \\
1972 \text { demographic } \\
\text { variables } \\
\text { percentile }\end{array}$} \\
\hline & 25 & 50 & 75 & 25 & 50 & 75 & 25 & 50 & 75 \\
\hline $1888-189$ & 1.59 & 1.62 & 1.80 & 2.41 & 2.26 & 2.16 & 2.19 & 2.08 & 2.06 \\
\hline & 86) & (1.22) & (2.76) & (2.76) & (1. & $(0.76)$ & (2.08) & (1. & $(0.70)$ \\
\hline $\begin{array}{l}\text { 1917-1919 } \\
\text { w/vacation }\end{array}$ & $\begin{array}{r}1.79 \\
(0.33)\end{array}$ & & & $\begin{array}{r}1.97 \\
(0.36)\end{array}$ & & & $\begin{array}{r}1.94 \\
0.41)\end{array}$ & & $\begin{array}{r}1.70 \\
0.21)\end{array}$ \\
\hline $1917-1$ & $\begin{array}{r}1.65 \\
(0.38)\end{array}$ & $\begin{array}{r}1.60 \\
(0.26)\end{array}$ & $\begin{array}{r}1.46 \\
(0.23)\end{array}$ & $\begin{array}{r}1.78 \\
(0.40)\end{array}$ & $\begin{array}{r}1.73 \\
(0.26)\end{array}$ & $\begin{array}{r}1.60 \\
(0.22)\end{array}$ & $\begin{array}{r}1.76 \\
(0.47)\end{array}$ & $\begin{array}{r}1.72 \\
(0.32)\end{array}$ & $\begin{array}{r}1.58 \\
(0.26)\end{array}$ \\
\hline $\begin{array}{r}1935- \\
\text { urb }\end{array}$ & $\begin{array}{r}1.28 \\
(0.48)\end{array}$ & $\begin{array}{r}1.25 \\
(0.33)\end{array}$ & $\begin{array}{r}1.26 \\
(0.10)\end{array}$ & $\begin{array}{r}1.29 \\
(0.49)\end{array}$ & $\begin{array}{r}1.26 \\
(0.33)\end{array}$ & $\begin{array}{r}1.27 \\
(0.10)\end{array}$ & $\begin{array}{r}1.29 \\
(0.52)\end{array}$ & $\begin{array}{r}1.26 \\
(0.34)\end{array}$ & $\begin{array}{r}1.27 \\
(0.10)\end{array}$ \\
\hline rural & $\begin{array}{r}1.24 \\
(0.78)\end{array}$ & $\begin{array}{r}1.18 \\
(0.52)\end{array}$ & $\begin{array}{r}1.16 \\
(0.24)\end{array}$ & $\begin{array}{r}1.22 \\
(0.77)\end{array}$ & $\begin{array}{r}1.17 \\
(0.51)\end{array}$ & $\begin{array}{r}1.15 \\
(0.24)\end{array}$ & $\begin{array}{r}1.22 \\
(0.98)\end{array}$ & $\begin{array}{r}1.17 \\
(0.75)\end{array}$ & $\begin{array}{r}1.15 \\
(0.50)\end{array}$ \\
\hline $\begin{array}{l}\text { restric } \\
1972-\end{array}$ & $\begin{array}{r}1.46 \\
(0.29)\end{array}$ & $\begin{array}{r}1.38 \\
(0.19)\end{array}$ & $\begin{array}{r}1.31 \\
(0.03)\end{array}$ & $\begin{array}{r}1.54 \\
(0.31)\end{array}$ & & $\begin{array}{r}1.38 \\
(0.03)\end{array}$ & $\begin{array}{r}1.54 \\
(0.31)\end{array}$ & $\begin{array}{l}1.40 \\
(0.19)\end{array}$ & $\begin{array}{r}1.38 \\
(0.03)\end{array}$ \\
\hline $\begin{array}{l}\text { 1972-1972 } \\
\text { w/vacation }\end{array}$ & $\begin{array}{r}1.54 \\
(0.20)\end{array}$ & $\begin{array}{r}1.44 \\
(0.12)\end{array}$ & $\begin{array}{r}1.37 \\
(0.01)\end{array}$ & $\begin{array}{r}1.64 \\
(0.21)\end{array}$ & $\begin{array}{r}1.52 \\
(0.12)\end{array}$ & $\begin{array}{r}1.43 \\
(0.01)\end{array}$ & $\begin{array}{r}1.64 \\
(0.21)\end{array}$ & $\begin{array}{r}1.52 \\
(0.12)\end{array}$ & $\begin{array}{r}1.43 \\
(0.01)\end{array}$ \\
\hline 1991 & $\begin{array}{r}1.32 \\
(0.76)\end{array}$ & $\begin{array}{r}1.23 \\
(0.50)\end{array}$ & $\begin{array}{r}1.17 \\
(0.22)\end{array}$ & $\begin{array}{r}1.49 \\
(0.78)\end{array}$ & $\begin{array}{r}1.35 \\
(0.51)\end{array}$ & $\begin{array}{r}1.19 \\
(0.22)\end{array}$ & $\begin{array}{r}1.52 \\
(1.22)\end{array}$ & $\begin{array}{r}1.36 \\
(0.81)\end{array}$ & $\begin{array}{r}1.19 \\
(0.46)\end{array}$ \\
\hline & & & & & & & & & \\
\hline & $\begin{array}{r}1.56 \\
(0.32)\end{array}$ & $\begin{array}{r}1.45 \\
(0.18)\end{array}$ & $\begin{array}{r}1.36 \\
(0.02)\end{array}$ & $\begin{array}{r}1.56 \\
(0.32)\end{array}$ & $\begin{array}{r}1.46 \\
(0.18)\end{array}$ & $\begin{array}{r}1.39 \\
(0.02)\end{array}$ & $\begin{array}{r}1.57 \\
(0.48)\end{array}$ & $\begin{array}{r}1.47 \\
(0.28)\end{array}$ & $\begin{array}{r}1.39 \\
(0.04)\end{array}$ \\
\hline $\begin{array}{l}\text { 1972-1973 } \\
\text { w/vacatio }\end{array}$ & $\begin{array}{r}1.69 \\
(0.36)\end{array}$ & $\begin{array}{r}1.56 \\
(0.22)\end{array}$ & $\begin{array}{r}1.45 \\
(0.02)\end{array}$ & $\begin{array}{r}1.71 \\
(0.21)\end{array}$ & $\begin{array}{r}1.56 \\
(0.11)\end{array}$ & $\begin{array}{r}1.44 \\
(0.01)\end{array}$ & $\begin{array}{r}1.79 \\
(0.39)\end{array}$ & $\begin{array}{r}1.61 \\
(0.20)\end{array}$ & $\begin{array}{r}1.47 \\
(0.02)\end{array}$ \\
\hline 1991 & $\begin{array}{r}1.26 \\
(0.59)\end{array}$ & $\begin{array}{r}1.25 \\
(0.39)\end{array}$ & $\begin{array}{r}1.23 \\
(0.12)\end{array}$ & $\begin{array}{r}1.25 \\
(0.59)\end{array}$ & $\begin{array}{r}1.24 \\
(0.38)\end{array}$ & $\begin{array}{r}1.23 \\
(0.13)\end{array}$ & $\begin{array}{r}1.28 \\
(1.30)\end{array}$ & $\begin{array}{r}1.27 \\
(0.86)\end{array}$ & $\begin{array}{r}1.25 \\
(0.44)\end{array}$ \\
\hline
\end{tabular}

Note. The 1917-1919 definition of recreation that includes expenditures for vacations and excursions is more comparable to the 1888-1890 definition. The definition that excludes that vacations and excursions is more comparable to the 1935-1936 definition. Demographic variables included in the specifications for 1888-1890, 1917-1919, 1972-1973 and 1991 were age and age squared of the husband and the number of children and the number of children squared. Standard errors are in parentheses. Expenditure elasticities labeled restricted were estimated for husband-wife households above the poverty line where the huband was in the labor force and was below age 65 . The null hyphothesis of equality of elasticities was rejected for all year-wise pairs of elasticities evaluated at the 50th percentile. 
transportation expenditures (without which many recreational activities would not be possible). The decline in recreational expenditure elasticities was even sharper when reading materials were excluded from the definition of recreation and was slightly attenuated when transportation expenditures were included. However, the basic results remained unchanged. When vacation travel is included in the definition of recreation in 1972-1973 expenditure elasticities increase somewhat. Given that expenditure elasticities in 1917 were higher when excursions were included in the definition of recreation, the omission of vacation expenditures does not lead me to overestimate the decline in expenditure elasticities.

Table 6 examines trends in expenditure elasticities for the main subcomponents of recreation (reading materials, movies and live entertainment, home entertainment, sporting equipment, toys, clubs, and vacations). With the exception of clubs, the expenditure elasticity of all goods fell over the long-run. Expenditure elasticities for reading fell between 1888-1890 and 1917-1919, those for movies and live entertainment and for home entertainment between 1917-1919 and 1935-1936, and those for sporting equipment between 1935-1936 and 1972-1973. Over the long run, the share of reading and movies and live entertainment fell and that of home entertainment rose (see Table 3), suggesting that, because the elasticity of a good such as home entertainment was very high in 1917 , most of the decline in elasticities is due to declining expenditure elasticities of individual goods, not to changing shares.

The decline in overall recreational expenditures elasticities can be formally decomposed into the decline due to changes in shares and that due to changes in expenditure elasticities. If the overall elasticity at time $t, \epsilon_{t}$, is equal to $\sum w_{i t} \epsilon_{i t}$, where $w_{i t}$ is the share of $\operatorname{good} i$ in the recreation budget and $\epsilon_{i t}$ is its elasticity, then, the change in elasticities between 1917 and 1991 is

$$
\epsilon_{1917}-\epsilon_{i, 1991}=\sum\left(w_{i, 1917}-w_{i, 1991}\right) \epsilon_{i, 1917}+\sum w_{i, 1991}\left(\epsilon_{, 1917}-\epsilon_{i, 1991}\right) .
$$


Table 6: Expenditure Elasticity Estimates for Specific Recreational Goods, Estimated Using Demographic Variables

\begin{tabular}{|c|c|c|c|c|c|c|c|}
\hline & reading & $\begin{array}{l}\text { movies and } \\
\text { live enter- } \\
\text { tainment }\end{array}$ & $\begin{array}{l}\text { home } \\
\text { enter- } \\
\text { tainment }\end{array}$ & $\begin{array}{l}\text { sporting } \\
\text { equip- } \\
\text { ment }\end{array}$ & toys & clubs & $\begin{array}{c}\text { vacations } \\
\text { and ex- } \\
\text { cursions }\end{array}$ \\
\hline $1888-1890$ & $\begin{array}{r}1.34 \\
(1.61)\end{array}$ & & & & & & \\
\hline 1917-1919 & $\begin{array}{r}0.93 \\
(0.03)\end{array}$ & $\begin{array}{r}2.02 \\
(2.27)\end{array}$ & $\begin{array}{r}3.30 \\
(5.02)\end{array}$ & & $\begin{array}{r}1.29 \\
(3.25)\end{array}$ & $\begin{array}{r}1.42 \\
(11.29)\end{array}$ & $\begin{array}{r}2.70 \\
(5.63)\end{array}$ \\
\hline $\begin{array}{c}\text { 1935-1936 } \\
\text { urban }\end{array}$ & $\begin{array}{r}0.83 \\
(1.08)\end{array}$ & $\begin{array}{r}1.35 \\
(1.37)\end{array}$ & $\begin{array}{r}0.83 \\
(12.46)\end{array}$ & $\begin{array}{r}1.84 \\
(16.83)\end{array}$ & $\begin{array}{r}1.05 \\
(12.46)\end{array}$ & $\begin{array}{r}2.22 \\
(20.08)\end{array}$ & \\
\hline rural & $\begin{array}{r}1.00 \\
(1.80)\end{array}$ & $\begin{array}{r}1.43 \\
(2.56)\end{array}$ & $\begin{array}{r}0.79 \\
(7.35)\end{array}$ & $\begin{array}{r}1.38 \\
(45.72)\end{array}$ & $\begin{array}{r}0.77 \\
(20.13)\end{array}$ & $\begin{array}{r}1.94 \\
(61.28)\end{array}$ & \\
\hline $\begin{array}{l}1972-1973 \\
\text { restricted } \\
1991 \\
\text { restricted }\end{array}$ & $\begin{array}{r}1.05 \\
(2.48) \\
0.87 \\
(10.48)\end{array}$ & $\begin{array}{r}1.43 \\
(2.63) \\
1.55 \\
(10.70)\end{array}$ & $\begin{array}{r}0.94 \\
(1.05) \\
0.79 \\
(1.00)\end{array}$ & $\begin{array}{r}1.37 \\
(4.99) \\
1.84 \\
(10.60)\end{array}$ & $\begin{array}{r}0.75 \\
(51.90) \\
1.10 \\
(12.92)\end{array}$ & $\begin{array}{r}2.19 \\
(15.99) \\
1.72 \\
(1.66)\end{array}$ & $\begin{array}{r}1.72 \\
(0.73)\end{array}$ \\
\hline $\begin{array}{l}1972-1973 \\
\text { unrestricted } \\
1991 \\
\text { unrestricted }\end{array}$ & $\begin{array}{r}1.05 \\
(2.20) \\
1.06 \\
(20.14)\end{array}$ & $\begin{array}{r}1.44 \\
(2.39) \\
1.00 \\
(2.67)\end{array}$ & $\begin{array}{r}0.95 \\
(1.01) \\
0.95 \\
(0.92)\end{array}$ & $\begin{array}{r}1.44 \\
(5.79) \\
1.48 \\
(1.34)\end{array}$ & $\begin{array}{r}0.69 \\
(64.35) \\
0.57 \\
(0.44)\end{array}$ & $\begin{array}{r}2.19 \\
(12.34) \\
1.85 \\
(26.84)\end{array}$ & $\begin{array}{r}1.77 \\
(0.63)\end{array}$ \\
\hline
\end{tabular}

Note. All elasticities estimated at the 50th percentile. Home entertainment includes expenditures on musical instruments, sheet music, movie rentals, cable television and the purchase, repair, or rental of radios, televisions, stereos, and videocassette recorders. Demographic variables used in estimation were age and age squared of the husband and the number of children and the number of children squared. Standard errors are in parentheses. Expenditure elasticities labeled restricted were estimated for husband-wife households above the poverty line in which the husband was in the labor force and was below age 65 . 
This calculation yields $\sum\left(w_{i, 1917}-w_{i, 1991}\right) \epsilon_{i, 1917}=-2.85$ and $\sum w_{i, 1991}\left(\epsilon_{i, 1917}-\epsilon_{i, 1991}\right)=3.235$, implying that if only shares had changed then the overall recreational expenditure elasticity would have risen, but that because elasticities for each category of recreational goods fell, overall expenditure elasticities decreased.

\section{Explaining the Decline}

Potential explanations for the decline in recreational expenditure elasticities include rising real incomes, an increase in the time costs of the wealthy relative to the poor that has led the wealthy to substitute away from recreational goods, a shift from non-market to market goods accompanied by a disproportionate increase in the consumption of market recreation by poorer individuals, the public provision of the complements of recreational goods, declining prices of recreational goods, and exogenous declines in hours worked.

Table 7 presents estimates of 1888-1890 and 1935-1936 consumer expenditure elasticities evaluated at the 1917 demographic means and inflation adjusted percentiles and the 1972 and 1935-1936 consumer expenditure elasticities evaluated at the 1991 means and inflation adjusted percentiles. I do not evaluate all of the elasticities at the percentiles of the same year because the deviation of the cubic polynomial specification from the kernel regressions at tails suggests that out of sample prediction is likely to be extremely poor. ${ }^{21}$ A comparison of Tables 5 and 7 suggests that increases in income explain only 38 percent of the decline in expenditure elasticities from 1888-1890 to 1917-1919, none from 1917-1919 to 1935-1936, and none from 1972-1973 to 1991. Even an overestimated rate of inflation from 1972-1973 to 1991 would not invalidate this conclusion because evaluating the 1972-1973 elasticities at the 1991 percentiles suggests that I

\footnotetext{
${ }^{21}$ In some cases out of sample prediction yields negative elasticities.
} 
Table 7: Recreational Expenditure Elasticities Evaluated at Different Demographic Means and Percentiles

\begin{tabular}{|c|c|c|c|}
\hline & \multicolumn{3}{|c|}{ Percentile } \\
\hline & 25 & 50 & 75 \\
\hline \multicolumn{4}{|l|}{ Evaluated at } \\
\hline \multicolumn{4}{|l|}{1917 demographic means and percentiles } \\
\hline \multirow[t]{2}{*}{ 1888-1890 survey } & 2.04 & 2.03 & 2.01 \\
\hline & $(0.60)$ & $(0.50)$ & $(0.43)$ \\
\hline \multirow[t]{2}{*}{ 1917-1919 survey (w/vacation) } & 1.97 & 1.89 & 1.72 \\
\hline & $(0.36)$ & $(0.22)$ & $(0.18)$ \\
\hline \multirow[t]{2}{*}{ 1917-1919 survey (w/o vacation) } & 1.78 & 1.73 & 1.60 \\
\hline & $(0.40)$ & $(0.26)$ & $(0.22)$ \\
\hline \multirow[t]{2}{*}{ 1935-1936, urban } & 1.29 & 1.27 & 1.26 \\
\hline & $(0.67)$ & $(0.57)$ & $(0.23)$ \\
\hline \multirow[t]{2}{*}{ 1935-1936, rural } & 1.16 & 1.16 & 1.16 \\
\hline & $(0.71)$ & $(0.69)$ & $(0.44)$ \\
\hline \multicolumn{4}{|l|}{ Evaluated at } \\
\hline \multicolumn{4}{|l|}{1991 demographic means and percentiles } \\
\hline \multirow[t]{2}{*}{ 1935-1936, urban } & 1.26 & 1.28 & 1.34 \\
\hline & $(0.39)$ & $(0.38)$ & $(0.15)$ \\
\hline \multirow[t]{2}{*}{ 1935-1936, rural } & 1.16 & 1.17 & 1.19 \\
\hline & $(0.60)$ & $(0.72)$ & $(1.21)$ \\
\hline \multirow[t]{2}{*}{ 1972-1973 survey, restricted (w/o vacation) } & 1.59 & 1.50 & 1.41 \\
\hline & $(0.60)$ & $(0.37)$ & $(0.06)$ \\
\hline \multirow[t]{2}{*}{ 1972-1973 survey, restricted (w/vacation) } & 1.72 & 1.59 & 1.47 \\
\hline & $(0.43)$ & $(0.25)$ & $(0.16)$ \\
\hline \multirow[t]{2}{*}{1991 survey, restricted } & 1.49 & 1.35 & 1.19 \\
\hline & $(0.78)$ & $(0.51)$ & $(0.22)$ \\
\hline
\end{tabular}

Note. Standard errors in parentheses. 
previously underestimated the decrease in elasticities. ${ }^{22}$

Rising time costs of the wealthy relative to the poor that induce them to substitute away from recreational goods are an unlikely explanation of the decline in expenditure elasticities. Trends in wage inequality do not coincide with trends in expenditure elasticities. The premium to education fell from the 1890s to the late 1920s and leveled off during the 1930s (Goldin and Katz 1995; 1999). The wage structure then narrowed sharply during the 1940s but inequality in wage ratios between the skilled and the unskilled has returned to pre-World II levels.

It is also unlikely that the shift from non-market to market goods is the primary explanation. The early surveys did not interview farm populations and is unlikely that the shift was as pronounced among urban dwellers. Although most small cities in the past simply did not have a large enough population to support many market forms of activities such as permanent theaters or dance halls, elasticities in 1917 were fairly similar between cities with a population of more than one million and those with a population of less than 25 thousand, implying that the shift from non-market to market goods has not had a large impact on the slope of Engel curves. ${ }^{23}$ Furthermore, elasticities in 1935-1936 were similar across urban and rural samples (see Table 5).

Declines in hours worked for lower income workers may explain part of the observed patterns in expenditure elasticities. ${ }^{24}$ In the 1890 s workers in the lowest decile of the wage distribution labored nearly 11 hours each day whereas those in the top decile worked 9 hour days. By the 1920s the hours distribution was much more egalitarian (Costa forthcoming). The

\footnotetext{
${ }^{22}$ Increases in income between 1888-1890 and 1935-1936 may be overestimated because of declines in relative prices, but even in this early period these declines are not large enough to produce a large increase in income.

${ }^{23}$ However, there is a tendency for elasticities at the 75 th percentile to be smaller in smaller cities. Perhaps there were so few recreational opportunities in small cities that after a given level of income had been reached, money could buy very little additional recreation.

${ }^{24}$ The reason for the hours decline is still unclear but may be related to rising incomes and to changes in the production process (Costa forthcoming). Owen (1969) argues that the increased availability of recreational goods increased demand for leisure. If so, then the ultimate cause for the decline in recreational expenditure elasticities is the diffusion of new goods.
} 
compression in the distribution of hours coincides with the compression in the distribution of recreational expenditures. Furthermore, increases in paid vacations during the 1950s and 1960s coincide with the decline in expenditure elasticities of sporting goods (see Table 6).

The compression in the distribution of recreational expenditures also coincides with the consumer revolution of the 1920s, when new goods such as radios and movies diffused rapidly throughout the population. In 1935-1936 92 percent of households in the urban survey reported owning a radio. Ninety-nine percent of households in the top total expenditure quartile owned a radio and 80 percent of households in the bottom quartile. Differences in piano ownership (one of the "older" forms of home entertainment) by total expenditure quartile were much greater. Forty-seven percent of households in the top quartile reported owning one compared to 23 percent in the bottom.

Although it is virtually impossible to obtain direct econometric evidence that the introduction of new goods, declining prices of existing goods and investments in public recreational facilities have lowered expenditure elasticities, the pattern of expenditure declines by recreational expenditure category is suggestive. Recall that Table 6 showed that the expenditure elasticity of reading declined primarily between 1888-1890, that of movies and live entertainment between 1917 and 1935, that of home entertainment between 1917 and 1935, and that of sporting equipment between 1935-1936 and 1972-1973. These periods of decline coincide with periods of innovation during which new goods were introduced, prices declined, demand increased, quality rose, and the public provision of goods complementary to recreation increased. Expenditure elasticities for reading fell precisely when circulation was rising rapidly and the price of newspapers and magazines fell by more than 15 percent. In the first decade of the nineteenth century, most seats for vaudeville shows cost 25 to 50 cents, but by 1905 moving picture tickets cost only 5 to 10 cents (Costa 1998: 149). Although the price of movie admissions rose between 1919 and 1935 whereas elasticities fell, the quality of movies increased sharply, particularly with the introduction 
of sound, and movie attendance rose nine-fold. Elasticities for sporting equipment fell when the technical advances made by the armed forces in outdoor equipment during Work War II became available to consumers in the form of portable boats and tents and lighter sports equipment, when land availability increased because of suburbanization, when artificial lakes and reservoirs were constructed, and when paid vacation time increased. Elasticities for home entertainment fell precisely when the radio displaced musical instruments as the main form of home entertainment. If expenditures devoted to the radio in 1935 were spent on goods other than home entertainment then the expenditure elasticity of home entertainment among urban households would rise from 0.83 to 1.39. Accounting for the diffusion of other goods, such as the phonograph, which 19 percent of urban households in the top total expenditure quartile owned in 1935 and 18 percent in the lowest quartile, may further explain the decline in the expenditure elasticity of home entertainment from 3.3 in $1917-1919$ to 0.8 in $1935-1936$.

\section{Living Standards Revisited}

Tables 1 and 2, which showed trends in mean budget shares from 1888-1890 to 1991, can be used in conjunction with estimated Engel curves for recreation to assess trends in living standards. Because I showed that aggregation holds, for any year, I can estimate the increase in per capita total expenditures required to achieve the recreational budget share of another year, holding demographic characteristics constant, and compare this increase with the actual increase in expenditures. ${ }^{25}$

This calculation suggests that living standards have been improving more rapidly than implied by per capita expenditure trends between 1919 and 1935 and 1972 to 1991 . The national

\footnotetext{
${ }^{25}$ Because this estimation procedure does not account for the consumer surplus derived from new goods, it will lead me to underestimate the true decrease in the cost of living.
} 
income and product account estimates and the 1917-1919 Engel curve suggest that to achieve the 1935 recreational budget share would require an increase in per capita total expenditures of 1.2 percent per year at a time when per capita total expenditures were falling by 1.2 percent per year. ${ }^{26}$ Because the price of recreation was falling and because the Engel curve grew flatter between 1917-1919 and 1935-1936, an increase of 1.2 percent per year is probably a lower bound estimate. Using the Engel curve for food eaten at home and the change in the budget share of food eaten at home in Table 1 implies that real total expenditures per capita grew at 3.0 percent per year. However, because the price of food fell, this figure may be an upper bound estimate.

The 1972-1973 Engel curve implies that to achieve the 1991 recreational budget share would require an increase in per capita total expenditures of 3.6 percent per year, not the 1.8 percent actually observed. Using the 1972-1973 Engel curve for food eaten at home suggests that between 1972 and 1991 real per capita total expenditures increased by 2.7 percent, still substantially more than the observed increase. The Boskin Commission (Boskin et al. 1998) estimated that the bias in the Consumer Price Index was 1.1 percent per year, with a range of 0.8 to 1.6. Using the Engel curve for food suggests that the bias is 0.9 and therefore in the bottom range of their estimates whereas using the Engel curve for recreation implies that the bias is 1.8, somewhat greater than the top number in their range.

Differences in the trend in living standards as measured by recreational expenditures and by per capita income or expenditures are less striking between 1890 and 1917. Per capita GNP increased by 2.0 percent per year between 1890 and 1917. The 1888-1890 Engel curve suggests that the 1917 recreational budget could have been achieved with an increase in per capita GNP of 2.3 percent per year. Between 1935 and 1950 real consumption expenditures per capita

\footnotetext{
${ }^{26}$ The 1917-1919 and 1934-1936 consumer expenditure and the 1917-1919 Engel curve also imply that per capita total expenditures were increasing at a rate of 1.2 percent per year. The 1917-1919 and 1935-1936 surveys imply an increase of 3.7 percent per year, but these populations are probably not comparable.
} 
increased by 3.4 percent per year. The 1935 Engel curve implies that real per capita consumption expenditures increased by about 4 percent. ${ }^{27}$ Between 1950 and 1972 real consumption expenditures per capita increased by 2.8 per year. The 1972 Engel curve implies that real per capita consumption expenditures increased by 2.5 percent per year. ${ }^{28}$

The estimated Engel curves show that the primary beneficiaries of increases in living standards have been lower income workers. Between 1888-1890 and 1917-1919 and 1917-1935 the Engel curve for recreational expenditures flattened. Even during the rising wage inequality of the 1970s and 1980s the Engel curve for recreational expenditures flattened slightly. A household in 1888 that was in the bottom expenditure decile would have had to have its total expenditures rise by 204 percent to achieve the recreational budget share of a household that in 1991 was in the bottom decile. In contrast, the 1888 household that was in the top decile would have had to have its total expenditures rise by only 88 percent to enjoy the same recreational budget share as its counterpart in 1991.

\section{Conclusion}

I have used consumer expenditure surveys dating as far back as 1888 to document trends in the inequality of living standards. I was able to use demand analysis to make statements about the standard of living because, as I showed, Engel curves that are consistent with utility maximization can be constructed for each survey. Because recreation is the quintessional luxury good I was able to use Engel curves to determine whether increases in the budget share of recreation coincided with increases in real income. I found that between 1919 and 1935 and 1972 and 1991 per capita total

\footnotetext{
${ }^{27}$ Because prediction is outside the 90 th percentile, there is some noise in this estimate.

${ }^{28}$ The food shares in Table 2 are outside the range used in estimating Engel curves for food eaten at home. Using the numbers in Table 1 yields the smaller estimates of 2.2 percent per year between 1935 and 1950 and 1.7 percent per year between 1950 and 1972.
} 
expenditure probably underestimate the true increase in living standards but that between 1890 and 1919, 1935 and 1950, and 1950 and 1972 per capita total expenditures are good indicators of living standards. The increase in the budget share devoted to recreational expenditures implied that between 1919 and 1935 per capita real total expenditures per year were rising by 1.2 percent per year, not falling by 1.2 percent per year, and between 1972 and 1991 by 3.6 percent per year, twice as high as the 1.8 percent actually observed. Trends in recreational expenditures over the 1970s and 1980s therefore imply that the Boskin Commission's estimate of Consumer Price Index bias of 1.1 percent per year is a cautious one (Boskin et al. 1998; cf. Moulton and Moses 1997.) ${ }^{29}$ The primary beneficiaries of the unmeasured increases in per capita real total expenditures between 1919 and 1935 and 1972 and 1991 were lower income households. Because Engel curves convey information on the distribution of recreational budget shares I was able to document trends in the inequality of living standards. I showed that recreational expenditure elasticities fell from more than 2 at the beginning of this century to slightly more than one by the mid 1930s. The declining recreational expenditure elasticity implies that living standards increased most sharply among lower income households. A comparison of recreational budget shares between 1888 and 1991 showed that the percentage increase in income needed by the 1888 household to achieve the 1991 budget shares was more than twice as high for households in the bottom decile of the total expenditure distribution than for households in the top decile. Recreational expenditure elasticities even fell slightly during the rising income inequality of the 1970s and 1980s, suggesting that criticisms of the Boskin Commission's findings on the grounds that a separate CPI for the poor would grow more rapidly are unfounded.

Recreation budget shares are indicators of living standards not just because of their uses in demand analysis, but also because they provide some suggestive evidence on trends in

\footnotetext{
${ }^{29}$ Using trends in the share of expenditures devoted to food suggests that the bias is about 0.9 percent per year. The overall bias may therefore be anywhere from 0.9 to 1.8 percent per year.
} 
work hours. This evidence is particularly useful because prior to 1940 relatively little is known about the distribution of work hours. Because recreational goods and leisure are complements my results therefore suggest that hours of work have fallen for lower relative to higher income workers and that the relative decline in hours worked was particularly sharp prior to 1940 . One explanation for the decline in expenditure elasticities may therefore be the compression in the hours distribution.

Technological change and investments in public goods were other factors explaining the decline in expenditure elasticities. Technological change has often been treated as the culprit in the widening of the income distribution (e.g. Berman et al. 1994), but it probably narrowed the distribution of recreational expenditures. Most this narrowing occurred from 1917-1919 to 19351936 and therefore coincides with the consumer revolution of the 1920s and the narrowing of the hours distribution. It may therefore be time to reassess the 1920s and the 1930s. Child health was improving even during the Great Depression, perhaps because of public health investments. ${ }^{30}$ This paper suggests that trends in health were not an anomaly. Changes in the consumption bundle of households and declines in inequality in recreation suggest that improvements in living standards may have been much more rapid, particularly among lower income households, than suggested by income measures alone. These gains may have been so large that even the income declines of Great Depression were not enough to reverse them.

\section{Appendix}

\footnotetext{
${ }^{30}$ Studies of child weight gains found no evidence of a Great Depression effect (e.g. Palmer 1934).
} 
Table 8: Expenditure Elasticities by Commodity Type, 1888-1991

\begin{tabular}{|c|c|c|c|c|c|c|}
\hline & $\begin{array}{l}1888- \\
-1890\end{array}$ & $\begin{array}{l}1917- \\
-1919\end{array}$ & $\begin{array}{c}\text { 1935-1936 } \\
\text { urban }\end{array}$ & $\begin{array}{l}1972- \\
\text { rural }\end{array}$ & $\begin{array}{c}1991 \\
-1973\end{array}$ & 1991 \\
\hline \multirow[t]{2}{*}{ Food } & 0.799 & 0.560 & 0.677 & 0.795 & 0.587 & 0.587 \\
\hline & $(0.011)$ & $(0.009)$ & $(0.020)$ & $(0.030)$ & $(0.026)$ & $(0.067)$ \\
\hline \multirow[t]{2}{*}{ Food at home } & & 0.532 & 0.538 & 0.753 & 0.405 & 0.426 \\
\hline & & $(0.009)$ & $(0.022)$ & $(0.033)$ & $(0.037)$ & $(0.085)$ \\
\hline \multirow[t]{2}{*}{ Shelter } & & 1.036 & 0.831 & 1.589 & 0.896 & 1.021 \\
\hline & & $(0.045)$ & $(0.079)$ & $(0.330)$ & $(0.057)$ & $(0.041)$ \\
\hline \multirow[t]{2}{*}{ Apparel } & 0.982 & 1.306 & 1.178 & 0.689 & 1.110 & 1.274 \\
\hline & $(0.039)$ & $(0.025)$ & $(0.111)$ & $(0.117)$ & $(0.099)$ & $(0.527)$ \\
\hline \multirow[t]{2}{*}{ Utilities } & 0.543 & 0.577 & 0.410 & 1.045 & 0.441 & 0.366 \\
\hline & $(0.125)$ & $(0.068)$ & $(0.120)$ & $(0.186)$ & $(0.001)$ & $(0.165)$ \\
\hline \multirow[t]{2}{*}{ Furniture and equipment } & 2.153 & 1.863 & 1.463 & 1.089 & 1.270 & 1.670 \\
\hline & $(0.799)$ & $(0.186)$ & (1.329) & (1.103) & $(0.254)$ & (1.479) \\
\hline \multirow[t]{2}{*}{ Transportation } & & 2.402 & 1.715 & 1.349 & 1.403 & 1.356 \\
\hline & & $(0.003)$ & $(0.189)$ & $(0.176)$ & $(0.046)$ & $(0.211)$ \\
\hline \multirow[t]{2}{*}{ Health } & 1.021 & 1.441 & 1.100 & 0.836 & 0.642 & 0.797 \\
\hline & $(0.537)$ & $(0.243)$ & $(0.472)$ & $(0.492)$ & $(0.171)$ & $(0.556)$ \\
\hline \multirow[t]{2}{*}{ Education } & & 1.616 & 1.756 & 1.013 & 2.291 & 1.514 \\
\hline & & $(0.001)$ & $(8.481)$ & $(8.683)$ & $(3.925)$ & (10.602) \\
\hline \multirow[t]{2}{*}{ Recreation } & 2.261 & 1.732 & 1.263 & 1.167 & 1.456 & 1.346 \\
\hline & (1.250) & $(0.261)$ & $(0.329)$ & $(0.512)$ & (0.192) & $(0.506)$ \\
\hline \multirow[t]{2}{*}{ All goods except recreation } & 0.979 & 0.976 & 0.989 & 0.993 & 0.956 & 0.978 \\
\hline & $(0.002)$ & $(0.001)$ & $(0.002)$ & $(0.002)$ & $(0.002)$ & $(0.005)$ \\
\hline
\end{tabular}

Note. All elasticities are estimated the regression $w=\alpha+\beta_{1} \log (z)+\beta_{2} \log ^{2}(z)+\beta_{3} \log ^{3}(z)+\beta_{4} x$ where $w$ is the budget share of recreation, $z$ is total expenditures, and $x$ is a vector of demographic characteristics (age and its squared and number of children and its square). All elasticities are evaluated at the 50th percentile and at the mean of the 1972 demographic characteristics. The 1972 and 1991 data were restricted to husband and wife families above the poverty line in which the husband was employed and was below age 65 to ensure compatibiltiy with earlier surveys. 


\section{References}

[1] Abbott, Michael and Orley Ashenfelter. 1976. "Labour Supply, Commodity Demand and the Allocation of Time." Review of Economic Studies.

[2] Berman, Eli, John Bound, and Zvi Griliches. 1994. "Changes in the Demand for Skilled Labor Within U.S. Manufacturing: Evidence from the Annual Survey of Manufactures." Quarterly Journal of Economics. 109 (May): 367-97.

[3] Blackorby, Charles and David Donaldson. 1994. "Measuring the cost of children: a theoretical framework." In Richard Blundell, Ian Preston, and Ian Walker (Eds), The Measurement of Household Welfare. Cambridge: Cambridge University Press.

[4] Banks, James, Richard Blundell, and Arthur Lewbel. 1997. "Quadratic Engel Curves and Consumer Demand." The Review of Economics and Statistics. 79(4, November): 527-539.

[5] Boskin, Michael J., Ellen R. Dulberger, Robert J. Gordon, Zvi Griliches, and Dale W. Jorgenson. 1998. "Consumer Prices, the Consumer Price Index, and the Cost of Living." The Journal of Economic Perspectives. 12(1): 3-26.

[6] Coleman, Mary T. and John Pencavel. 1993a. "Changes in Work Hours of Male Employees, 1940-1988.” Industrial and Labor Relations Review. 46(2, January): 262-283.

[7] Coleman, Mary T. and John Pencavel. 1993b. "Trends in Market Work Behavior of Women Since 1940." Industrial and Labor Relations Review. 46(4, July): 653-76.

[8] Converse, Philip E. and John P. Robinson. 1980. Americans' Use of Time, 1965-1966. ICPSR 7254. Ann Arbor, MI: Inter-university Consortium for Political and Social Research.

[9] Costa, Dora L. Forthcoming. "The Wage and the Length of the Work Day: From the 1890s to 1991." Journal of Labor Economics.

[10] Costa, Dora L. 1998. The Evolution of Retirement: An American Economic History, 18801990. University of Chicago Press for NBER.

[11] Costa, Dora L. and Richard H. Steckel. 1997. "Long-term Trends in U.S. Health, Welfare, and Economic Growth." In Richard H. Steckel and Roderick Floud (Eds), Health and Welfare During Industrialization. Chicago: University of Chicago Press.

[12] Cutler, David M., Mark McClellan, Joseph P. Newhouse, and Dahlia Remler. 1998. "Are Medical Prices Declining? Evidence from Heart Attack Treatments." Quarterly Journal of Economics. 113(4): 991-1024.

[13] Dewhurst, J. Frederic, and Associates. 1955. America's Needs and Resources. New York: The Twentieth Century Fund. 
[14] Fogel, Robert W. 1999. "Catching up with the Economy." American Economic Review. 89(1): 1-21.

[15] Goldin, Claudia and Larry Katz. 1999. "Education and Income in the Early 20th Century: Evidence from the Prairies, 1915 to 1950.” Unpublished manuscript. Harvard University.

[16] Goldin, Claudia and Larry Katz. 1995. "The Decline of Non-Competing Groups: Changes in the Premium to Education, 1890 to 1940.” National Bureau of Economic Research Working Paper, No. 5202.

[17] Goldin, Claudia and Robert A. Margo. 1992. "The Great Compression: The Wage Structure in the United States at Mid-Century." Quarterly Journal of Economics. 107(1): 1-34.

[18] Hamilton, Bruce W. 1998. “The True Cost of Living: 1974-1991.” Working Papers in Economics, The Johns Hopkins University Department of Economics, January 1998.

[19] Härdle, Wolfgang. 1990. Applied Nonparametric Regression. Cambridge: Cambridge University Press.

[20] Hausman, J.A., W.K. Newey, J.L. Powell. 1995. "Nonlinear errors in variables. Estimation of some Engel curves." Journal of Econometrics. 65: 205-233.

[21] Komarovsky, M., G.A. Lundberg, M.A. McInerny. 1934. Leisure, A Suburban Study. New York: Columbia University Press.

[22] Lamale, Helen Humes. 1956. Study of Consumer Expenditures, Incomes and Savings: Methodology of the Survey of Consumer Expenditures in 1950. Philadelphia: University of Pennsylvania.

[23] More, Louise Bolard. 1907. Wage-Earners' Budgets: A Study of Standards and Costs of Living in New York City. New York: H. Holt.

[24] Moulton, Brent R. and Karin E. Moses. 1997. "Addressing the Quality Change Issue in the Consumer Price Index." Brookings Papers on Economic Activity, 1. Washington DC: The Brookings Institute.

[25] Nakamura, Leonard. 1997. "Is the U.S. Economy Really Growing Too Slowly? Maybe We're Measuring Growth Wrong.” Federal Reserve Bank of Philadelphia Business Review. March-April 1997: 3-14.

[26] Nordhaus, William D. 1997. "Do Real-Output and Real-Wage Measures Capture Reality? The History of Lighting Suggests Not.” Timothy F. Bresnhan and Robert J. Gordon (Eds), The Economics of New Goods. Chicago: University of Chicago Press.

[27] Owen, John D. 1964. "The Supply of Labor and the Demand for Recreation in the United States, 1900-1961.” Unpublished Phd Dissertation. Columbia University. 
[28] Owen, John D. 1969. The Price of Leisure: An Economic Analysis of the Demandfor Leisure Time. Rotterdam: Rotterdam University Press.

[29] Palmer, C.E. 1934. "Further studies on growth and the economic depression. A comparison of weight and weight increments of elementary schoolchildren in 1921-27 and in 1933-34." Public Health Reports. Washington DC, 49: 1453-69.

[30] Robinson, John. 1993. Americans' Use of Time, 1985. ICPSR 9875. Ann Arbor, MI: Interuniversity Consortium for Political and Social Research.

[31] Schor, Juliet B. 1991. The Overworked American: The Unexpected Decline of Leisure. Basic Books.

[32] United States Bureau of the Census. 1975. Historical Statistics of the United States, Colonial Times to 1970. Washington DC: Government Printing Office.

[33] United States Bureau of the Census. 1993. Statistical Abstract of the United States: 1993. Washington, DC: Government Printing Office.

[34] United States Bureau of Labor Statistics. 1998. Handbook of U.S. Labor Statistics: Employment, Earnings, Prices, Productivity, and Other Labor Data. Lanhan, MD: Bernan Press.

[35] United States Department of Labor. 1986. Cost of Living of Industrial Workers in the United States and Europe, 1888-1890. ICPSR 7711. Ann Arbor, MI: Inter-university Consortium for Political and Social Research.

[36] United States Department of Labor. Bureau of Labor Statistics. 1986. Cost of Living in the United States, 1917-1919. ICPSR 8299. Ann Arbor, MI: Inter-university Consortium for Political and Social Research.

[37] United States Department of Labor. Bureau of Labor Statistics. 1941. Money Disbursements of Wage Earners and Clerical Workers, 1934-36. Summary Volume. Bulletin No. 638. Washington DC: Government Printing Office.

[38] United States Department of Labor. 1959. How American Buying Habits Change. Washington DC: Government Printing Office.

[39] United States Department of Labor. Bureau of Labor Statistics. 1987. Survey of Consumer Expenditures, 1972-1973. ICPSR 9034. Ann Arbor, MI: Inter-university Consortium for Political and Social Research.

[40] United States Department of Labor. Bureau of Labor Statistics. 1991. Consumer Expenditure Survey, Interview Survey Public Use Tape, 1991. 
[41] United States Department of Labor. Bureau of Labor Statistics, Wharton School of Finance and Commerce. University of Pennsylvania. 1956. Study of Consumer Expenditures, Incomes and Savings, 1950. Philadephia: University of Pennsylvania.

[42] United States Department of Labor, Bureau of Labor Statistics and United States Department of Agriculture, Bureau of Home Economics, et al. 1999. Study of Consumer Purchases in the United States, 1935-1936. ICPSR 8908. Ann Arbor, MI: Inter-university Consortium for Political and Social Research. 